\title{
Couro ruim é que chama ferrão de ponta: a respeito da violência em Grande
}

\author{
sertão: veredas
}

DOI: https://doi.org/10.22409/pragmatizes.v10i18.38867

\author{
Júlio França ${ }^{1}$ \\ João Pedro Lima Bellas²
}

Resumo: O presente artigo propõe uma leitura de Grande sertão: veredas (1956), de Guimarães Rosa, sob a perspectiva das "poéticas do mal". Partimos de observações e descrições feitas em um artigo anterior, em que demonstrávamos ser o medo um elemento temático e estrutural fundamental no romance rosiano. Dando continuidade a essa abordagem, nossa proposta é considerar especificamente a violência, tanto em sua dimensão temática quanto em sua função formal na narrativa. A hipótese a ser desenvolvida é que a violência também se configura como um elemento essencial da história de Riobaldo, não possuindo em si mesma um valor positivo ou negativo, uma vez que surge ora como um produto dos receios experimentados pelo protagonista, ora como um meio de conciliar e superar os seus temores.

Palavras-chave: Guimarães Rosa; Grande sertão: veredas; poéticas do mal; medo; violência.

\section{Cuero ruin reclama punzón puntiagudo: sobre la violencia en Gran sertón: veredas}

Resumen: El presente artículo propone una lectura de Gran sertón: veredas (1956), de Guimarães Rosa, desde la perspectiva de las "poéticas del mal". Partimos de observaciones y descripciones hechas en un artículo anterior, en que demostrábamos ser el miedo un elemento temático y estructural fundamental da la novela rosiana. Continuando con ese abordaje, proponemos ahora considerar específicamente la violencia, tanto en su dimensión temática como en su función formal en la narrativa. Se desarrollará la hipótesis de que también la violencia se configura como un elemento esencial del relato de Riobaldo, no teniendo en sí misma un valor positivo o negativo, ya que surge ora como un producto de las aprensiones experimentadas por el protagonista, ora como una manera de conciliar y superar sus temores.

Palabras clave: Guimarães Rosa; Gran sertón: veredas; poéticas del mal; miedo; violencia.

\section{Tough hides call for a sharp goad: on violence in The Devil to Pay in the Backlands}

Abstract: This paper presents a reading of The Devil to Pay in the Backlands that relates the novel with the tradition of the "poetics of evil" and builds on a broader approach we've been developing. It

\footnotetext{
${ }^{1}$ Júlio César França Pereira. Doutor em Literatura Comparada pela Universidade Federal Fluminense (UFF). Professor do Programa de Pós-Graduação em Letras da Universidade do Estado do Rio de Janeiro (UERJ), Brasil. E-mail: julfranca@gmail.com - ORCID: https:// orcid.org/0000-0002-6293-8235

2 João Pedro Lima Bellas: Doutorando em Literatura Comparada pela Universidade Federal Fluminense, Brasil. E-mail: joaolbellas@gmail.com - ORCID: https://orcid.org/0000-0002-2982-6661
} 
consists of an interpretation that takes fear as a thematic and structural element in Guimarães Rosa's novel. Thus, our proposition is to take violence as our main subject and put forth an analysis that relates it with the element of fear. Our hypothesis is that violence is also a fundamental component in Riobaldo's narrative, emerging, at times, as a byproduct of the protagonist's fears, but also as a way of reconciling and overcoming his terrors.

Keywords: Guimarães Rosa; The Devil to Pay in the Backlands; poetics of evil; fear; violence.

\section{Grande sertão: veredas e as poéticas do mal}

Romance basilar na tradição literária brasileira, Grande sertão:veredas (1956) é daquelas obras que, como observou Antonio Candido (cf. 1964), oferecem ao leitor uma miríade de temas e símbolos de modo a sustentar uma gama igualmente ampla de interpretações, que vão desde leituras que enfatizam a sua experimentação linguística até as que ressaltam significados que perpassam domínios variados como o da filosofia, da sociologia, da psicanálise ou da religião.Ainda que sejam altos os riscos de se propor uma nova abordagem do romance rosiano, tendo em vista a extensão de sua fortuna crítica, temos nos dedicado a ler Grande sertão a partir das relações que a obra estabelece com as "poéticas do mal"3 - uma perspectiva

\footnotetext{
${ }^{3}$ Chamamos de "poéticas do mal" aos modos de fazer artístico que se caracterizam por privilegiar a representação e a expressão de aspectos negativos da experiência e do
}

que nos parece ainda pouco ou nada explorada.

Em ensaio recente, propusemos duas hipóteses centrais, que serão desenvolvidas em estudos subsequentes, como é o caso deste artigo. A primeira dessas hipóteses consiste na defesa de que Grande sertão: veredas é uma narrativa que se estrutura a partir de "uma reflexão sobre o mundo impregnado pelo Mal" (FRANÇA, 2020, p. 2); a segunda é a ideia de que "é a profunda experiência do medo que dá sentido à existência de Riobaldo - e, por conseguinte, estrutura a narração de sua vida" (FRANÇA, 2020, p. 2). Tais hipóteses foram construídas após a observação da recorrência, no romance, do termo "medo" (precisamente, 181 ocorrências) e termos sinônimos como "horror", "receio" e "temor". Para além

imaginário humanos. Para um aprofundamento do assunto ver França e Araújo (2018). 
dessa observação objetiva, uma leitura pela chave do medo é ainda justificada pela constatação de que momentos cruciais da narração de Riobaldo como, por exemplo, o encontro na infância com Diadorim às margens do São Francisco; o reconhecimento de Hermógenes como o mal a ser enfrentado; o pacto com o diabo; a tomada de poder no bando de Zé Bebelo - são descritos em função da experiência do medo, seja no sentido de identificá-lo, seja para enfrentá-lo ou superá-lo.

O medo é, portanto, um tema que atravessa a narrativa de Riobaldo e se constitui como um elemento central para a dimensão ética do romance:

Com seu ritmo memorialístico errático, Grande sertão: veredas é, em grande medida, um romance de formação. E, como tal, um de seus temas axiais é o das escolhas éticas: como se deve viver, qual é o caminho certo a seguir, qual é o descaminho. Como o que somos é o resultado direto de nossas escolhas, e a sabedoria nada mais é do que ser capaz de fazer as escolhas corretas, o medo torna-se um grande mal porque corrompe nosso discernimento, e nos faz tomar decisões erradas, isto é, covardes. Esse é o motivo principal pelo qual se deve temer sentir medo - um estado afetivo capaz de nublar nossa consciência, nosso entendimento e nossa razoabilidade. (FRANÇA, 2020, p. 12)
A abordagem de Grande sertão pelo viés das poéticas do mal, além de realçar um aspecto do romance pouco (ou nada) explorado pela tradição crítica brasileira, permite-nos reavaliar e redimensionar alguns traços da obra já reconhecidos e descritos pelos estudos literários. Um desses elementos é justamente a violência, o tema deste artigo.

Ela assume um papel fundamental na magnum opus rosiana, mas, ao contrário do medo, não se apresenta como um elemento inexplorado por estudos críticos sobre o romance. Dada a multiplicidade de sentidos engendrados pela obra total de Guimarães Rosa, várias são as perspectivas adotadas para a abordagem da violência. Ela pode ser interpretada em termos psicanalíticos (cf. BUENO, 2008), sociológicos (cf. ARNT, 2015) ou políticos (cf. GINZBURG, 1992), entre várias outras perspectivas. Ainda assim, se considerarmos a violência no âmbito das tradições literárias das poéticas do mal talvez seja possível explicitar sentidos que até agora passaram despercebidos em estudos anteriores.

O presente artigo propõe considerar o tema da violência dentro 
de uma perspectiva de leitura que entende a experiência do medo como estruturante da existência de Riobaldo. A hipótese que desdobraremos é a de que a violência ora surge como uma consequência negativa da covardia esta, por sua vez, um produto do medo -, ora como uma forma de apaziguamento e superação do medo onipresente na experiência de vida do narrador-protagonista.

\section{Riobaldo, jagunçagem, violência}

As reminiscências do narrador situam a narrativa em uma cronotopia em que a violência é uma constante. Há, dessa forma, em Grande sertão: veredas, muitos elementos e episódios que poderiam ser descritos como característicos das poéticas do mal. Citemos, como exemplos, os diversos loci horribiles, como as Veredas Tortas, onde se dará o pacto com 0 Diabo; ou o Liso do Sussuarão, "o miôlo mal do sertão" (ROSA, 2001, p.79), onde o protagonista irá se pôr a prova; e as muitas personagens descritas como monstruosas - como Hermógenes e os tantos desvalidos do sertão, tais quais os catrumanos da brenha. Mas são os inúmeros crimes e transgressões cometidos pela jagunçagem através do sertão alguns descritos de forma detalhada e explícita - que consistem no maior conjunto de representações de violência no romance.

Nesse sentido, é importante notar que um dos traços mais marcantes da narrativa de Riobaldo é a relação ambígua que ele mantém com seu passado de jagunço. Por um lado, o protagonista sente-se um estranho em meio àquela vida, e, algumas vezes, reluta em admitir que possui as qualidades necessárias a um jagunço, como ilustram as duas passagens a seguir: "o que me atazanava, a mór [...] era o significado que eu não achava lá, no meio em que eu estava obrigado, naquele grau de gente" (ROSA, 2001, p. 237); e "O jagunço Riobaldo. Fui eu? Fui e não fui. Não fui! - porque não sou, não quero ser" (ROSA, 2001, p. 280, grifos nossos). Por outro lado, em outros momentos de sua narração, Riobaldo parece não apenas naturalizar a vida jagunça - "Por quê eu ia ter pena dos outros? Algum tinha pena de mim...? [...] Matar, matar, quê que me importava?" (ROSA, 2001, p. 271) -, como também demonstra apreço por ela, como na ocasião em 
que tem sua valentia elogiada por Vupes: "o mais garboso fiquei, prezei a minha profissão. Ah, o bom costume de jagunço. Assim que é a vida soprada, vivida por cima" (ROSA, 2001, p. 106).

Conforme a narração avança, torna-se evidente que os sentimentos contraditórios que ele nutre pela vida de jagunço derivam, em grande medida, de seu entendimento sobre as causas e as consequências dos atos violentos perpetrados pelos jagunços. Esse aspecto do romance fica ainda mais claro se considerarmos que a violência é inerente ao sertão - ou, ao menos, na maneira como o sertão é concebido pelo protagonista. Isso é manifesto, por exemplo, na maneira como o narrador descreve Jazevedão, delegado que conseguiu pôr fim na jagunçagem e levar ordem ao sertão: "nunca vi cara de homem fornecida de bruteza e maldade mais, do que nesse" (ROSA, 2001, p. 42). Embora constate que 0 delegado é responsável por diversas barbaridades, Riobaldo mostra-se convencido de que a violência era 0 único meio de dar cabo do caos que permeava o sertão:
Conseguiu de muito homem e mulher chorar sangue, por este, por este simples universozinho aqui. Sertão. O senhor sabe: sertão é onde manda quem é forte, com as astúcias. Deus mesmo, quando vier, que venha armado! [...]

Tanto, digo: Jazevedão - um assim, devia de ter, precisava? Ah, precisa. Couro ruim é que chama ferrão de ponta. [...] Mas só do modo, desses, por feio instrumento, foi que a jagunçada se findou (ROSA, 2001, p. 43).

Para Riobaldo, portanto, em um mundo permeado por atos de violência e crueldade, apenas a força bruta é capaz de organizar o caos do sertão ou seja, a ordem é alcançada apenas quando se age de forma ainda mais violenta e cruel. A lógica do narradorprotagonista parece apontar que, em um mundo impregnado pelo mal, só é possível enfrentá-lo com o próprio mal. O romance, portanto, ao menos inicialmente,oferece-nos indícios de que Riobaldo parece assumir uma posição de suspensão de juízo em relação à violência, dadas as condições específicas do sertão: "Tudo naquele tempo, e de cada banda que eu fosse, eram pessoas matando e morrendo, vivendo numa fúria firme, [...] e eu não pertencia a razão nenhuma, não guardava fé e nem fazia parte" (ROSA, 2001, p. 190). 
Contudo, a indiferença de Riobaldo em relação à violência que assola o sertão não é constante no desenvolvimento do romance. $O$ narrador, por diversas vezes, deixa transparecer uma profunda inquietação ao presenciar atos de crueldade, ainda que, não raramente, demonstre uma profunda curiosidade por eles. Essa ambiguidade manifestase de modo exemplar na reação de nosso protagonista à sua nêmesis, Hermógenes. Desde o início de sua narração, Riobaldo expressa profunda repulsa por seu antagonista: "Eu não queria olhar para ele, encarar aquele carangonço; me perturbava" (ROSA, 2001, p. 226). Em dado momento de sua história, porém, o narrador nos diz:

[...] eu não queria pensar naquele Hermógenes, e o pensamento nele sempre me vinha, ele figurando, eu cativo. Ser que pensava, amiúde, em ele ser carrasco, como tanto se dizia, senhor de todas as crueldades. No começo, aquilo me corria só os calafrios de horror, a ideia minha refugava. Mas, a pouco, peguei às vezes uma ponta de querer saber como tudo podia ser, eu imaginava (ROSA, 2001, p. 298).

A passagem, ao ressaltar a tensão entre atração e repulsa fomentada pela personalidade de Hermógenes, serve como demonstração metonímica da dubiedade do pensamento do narrador acerca da violência que caracteriza a jagunçagem. O trecho é especialmente significativo por indicar que mesmo uma figura repugnante para Riobaldo e é importante dizer que tal aversão é, sobretudo, moral, e provocada principalmente pelo sadismo de Hermógenes - era capaz de incitar a sua imaginação e a sua curiosidade.

Hermógenes é uma das personagens centrais para que se compreenda os movimentos da narrativa, e, consequentemente, a vida de Riobaldo. Do ponto de vista do enredo, o antagonista é o responsável pela morte de Joca Ramiro, acontecimento que desencadeia a principal subtrama do romance: a campanha de vingança contra "os Judas" (ROSA, 2001, p. 64 et passim). A percepção de Riobaldo - de que Hermógenes é uma encarnação do mal - encontra eco, na diegese, na crença disseminada entre os jagunços de que Hermógenes firmou um pacto com o diabo. Essa suposição sobre sua condição de pactário pode ser entendida, alegoricamente, como uma tentativa de explicar, ainda que por meio de justificativas de cunho sobrenatural, uma tamanha maldade 
que parece exceder a capacidade de compreensão humana.

Fazendo eco à anteriormente mencionada constatação de que o mal somente pode ser combatido pelo próprio mal, Riobaldo, em dado momento de sua trajetória como jagunço, parece admitir a inevitabilidade e mesmo a própria justiça do uso da violência para se vingar de Hermógenes e Ricardão. Tal entendimento irá motivar uma série de decisões fulcrais na trajetória do protagonista, e redundará no pacto com o diabo, na tomada do poder de Zé Bebelo e, por fim, em sua ascensão como o "Urutú Branco" (ROSA, 2001, p. 545), chefe do bando que outrora pertenceu a Joca Ramiro. Nesse movimento, há uma escalada de atos de violência cometidos por Riobaldo, em uma progressão que o colocará, enfim,como um semelhante de seu antagonista: "A ironia trágica desse percurso do protagonista é bastante explícita. Agora é Riobaldo quem causa medo nos outros. Em grande medida, ele se transformou no tipo de monstro que combatia." (FRANÇA, 2020, p. 11). Para o velho Riobaldo, narrador do romance, essa trajetória é perturbadora, pois revela nele a disposição para - ou mesmo um apreço por - cometer atos violentos. Enquanto narra, ele busca através de um processo anamnésico, tanto lembrar quanto descobrir algo que venha a legitimar as ações que cometeu. E é precisamente essa busca por uma justificação que nos interessa mais especialmente, por sua relação direta com a experiência do medo.

\section{A violência como remédio contra o medo}

O papel de antagonista desempenhado por Hermógenes é um elemento central no enredo de Grande sertão, já que é em função dele que Riobaldo encontra uma justificativa para a sua própria tendência ao mal. Contudo, se pensarmos na formação do caráter do protagonista, nenhuma personagem é tão essencial como Diadorim. É na relação com ela que se definem aspectos centrais da vida e da personalidade do narrador. Nesse sentido, quando se lê a obra rosiana como um romance de formação, é observável que diversos pontos de virada fundamentais na narrativa de Riobaldo têm Diadorim como figura central e força motriz. Talvez nenhum 
deles seja tão significativo quanto a travessia do rio São Francisco (ROSA, 2001, p. 146-148), episódio que marca o primeiro encontro dos protagonistas, ainda na infância de ambos.

A travessia é recordada em um momento da narrativa em que já estamos familiarizados com a admiração que Riobaldo nutre por Diadorim. O que esse momento, especificamente, proporciona de mais relevante para nossa interpretação do romance é a revelação de que essa admiração do narrador nasce com o assombro da descoberta de que Diadorim não sente medo: "Você nunca teve medo?' - foi o que me veio, de dizer. Ele respondeu: Costumo não...' - e, passado o tempo dum meu suspiro: - 'Meu pai disse que não se deve de ter...' Ao que meio pasmei" (ROSA, 2001, p. 147-148). A assertiva de Diadorim não é apenas retórica, mas será confirmada, no episódio, tanto pela coragem que a personagem demonstra ao atravessar - caudaloso rio, em uma pequena canoa, mesmo sem saber nadar, quanto pelo enfrentamento, com um canivete na mão, de um potencial abusador (ROSA, 2001, p. 150).
O episódio da travessia do São Francisco permite-nos afirmar que, de certo modo, Diadorim também se apresenta como um oposto de Riobaldo, já que o narrador do romancese caracteriza exatamente por ser assombrado por seus medos. Sua história é marcada pelo desejo profundo de entender e superar os temores que perpassaram sua vida, impedindo-Ihe de seguir um caminho virtuoso.

Como a estima de Riobaldo por Diadorim nasce da admiração que o narrador manifesta pelo fato de 0 amigo jamais sentir medo, o convívio entre os dois personagens irá gerar uma associação entre coragem e bondade.Ao falar sobre Joca Ramiro para Riobaldo, Diadorim enfatiza que não há ninguém mais valente em todo o Gerais, e afirma na sequência: "Não sabe que quem é mesmo inteirado valente, no coração, esse também não pode deixar de ser bom?!" (ROSA, 2001, p. 200). Vale a pena lembrar que Ramiro, ao longo de todo romance, é descrito como uma figura quase divina:

E Joca Ramiro. A figura dele. Era ele, num cavalo branco - cavalo que me olha de todos os altos. Numa sela bordada, de Jequié, em lavores de preto-e-branco. As rédeas bonitas, grossas, não sei de que trançado. E ele era um homem de 
largos ombros, a cara grande, corada muito, aqueles olhos. Como é que vou dizer ao senhor? Os cabelos pretos, anelados? O chapéu bonito? Ele era um homem. Liso bonito. Nem tinha mais outra coisa em que se reparar. A gente olhava, sem pousar os olhos. A gente tinha até medo de que, com tanta aspereza da vida, do sertão, machucasse aquele homem maior, ferisse, cortasse. E, quando ele saía, o que ficava mais, na gente, como agrado em lembrança, era a voz. Uma voz sem pingo de dúvida, nem tristeza. Uma voz que continuava. (ROSA, 2001, p. 318)

A atribuição de um caráter divino a Joca Ramiro - e, por extensão, a valorização de sua bondade, justiça e coragem - é ratificado pelo termo utilizado para se referir aos seus assassinos - os "Judas". É nesse sentido que entendemos a jornada de Riobaldo para sobrelevar os seus receios como um esforço ético de não apenas superar o medo, mas, mais precisamente, como uma saga para tornar-se bom.

Das implicações existentes entre medo e mal, coragem e bem, decorre o ponto de vista ambíguo de Riobaldo sobre a violência. Em boa parte da diegese, o ódio, a intimidação física e moral de terceiros são meios de enfrentamento do seu próprio medo. Em outras palavras, no sertão, mergulhar no modo de vida jagunço e praticar toda sorte de maldades integra uma condição necessária no processo formativo de se tornar bom, como parece indicar a seguinte alusão à sabedoria dos jagunços: "A vida é para esse sarro de medo se destruir; jagunço sabe" (ROSA, 2001, p. 460).

A indicação de que o ódio é um caminho incontornável para alcançar a coragem, e, assim, tornar-se bom, é bastante explícito na percepção de Riobaldo acerca de qual posição deve assumir frente ao Hermógenes:"O ódio pousa na gente, por umas criaturas. Já vai que o Hermógenes era ruim, ruim. Eu não queria ter medo dele" (ROSA, 2001, p. 224). A ênfase na maldade intrínseca do antagonista parece ser voltada para explicitar e justificar o ódio. Em outras palavras, Riobaldo mais uma vez demonstra uma profunda preocupação em justificar uma emoção negativa. Essa justificativa é organizada de modo a apresentar o ódio como necessário e, portanto, não como um sentimento negativo, mas como um antídoto contra o medo que seu antagonista lhe inspira.

Consequentemente, conversão do ódio em violência parece ser vista como um percurso quase 
natural, uma vez que, como foi explicitado, Riobaldo compreende-a como uma marca estrutural não apenas da vida jagunça mas do próprio sertão. Isso parece ser corroborado pela receita dada pelo protagonista para adquirir coragem:

\begin{abstract}
O que há, que se diz e se faz - que qualquer um vira brabo corajoso, se puder comer cru o coração de uma onça-pintada. E, mas, a onça, a pessoa mesma é quem carece de matar; mas matar à mão curta, a ponta de faca! Pois, então, por aí se vê, eu já vi: um sujeito medroso, que tem muito medo natural de onça, mas que tanto quer se transformar em jagunço valentão - e esse homem afia sua faca, e vai em soroca, capaz que mate a onça, com muita inimizade; o coração come, se enche das coragens terríveis! (ROSA, 2001, p. 207)
\end{abstract}

O ato capaz de tornar os homens valentes é marcado, portanto, pela violência. Não basta apenas matar a onça; deve fazê-lo a partir de um embate direto, "à mão curta, a ponta de faca", que culmina em um ato bastante cruel, quando se come, cru, o coração da onça. É interessante observar que o próprio Riobaldo parece consciente da contradição de seu raciocínio, já que define a coragem adquirida como aterrorizante: "o coração come, se enche das coragens terríveis!".
O que parece perturbar 0 narrador, porém, é o reconhecimento de que o ódio, como antídoto para enfrentar o medo, tem efeitos colaterais poderosos. Quando se é efetivamente bem-sucedido na superação do próprio medo, o sujeito torna-se, ele próprio, uma fonte de pavor para os outros, realimentando assim o ciclo de medo, ódio e violência. No romance, isso é concretizado quando Riobaldo se torna o Urutú-Branco e assume a liderança dos jagunços, o que se confirma pela fala que Ihe é dirigida por Zé Bebelo, destituído do posto de chefe: "você é o outro homem, você revira o sertão... Tu é terrível, que nem um urutú branco..." (ROSA, 2001, p. 545).

Esse encadeamento reflexivo conduz Riobaldo a uma aporia, pois parece não ser possível escapar do medo. Nesse caso, a suspensão de juízo a respeito da violência precisa, consequentemente, ser revista. Assim, se, em um primeiro momento, o romance parecia caminharem direção a uma posição de neutralidade do protagonista frente aos atos de crueldade que presencia pelo sertão, Riobaldo, conforme avança em sua narração, torna-se mais consciente de 


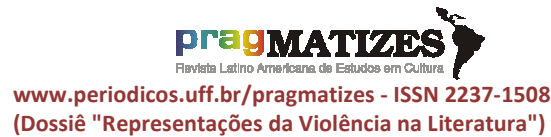

que a violência está imbricada à própria natureza humana: "Digo ao senhor: remorso? Como no homem que a onça comeu, cuja perna. Que culpa tem a onça, e que culpa tem o homem?" (ROSA, 2001, p. 395). Na recusa ao remorso, bem como na analogia com um animal, Riobaldo parece aceitar, não sem algum grau de desencanto, a natureza violenta do ser humano:"A gente viemos do inferno nós todos - compadre meu Quelemém instrui. Duns lugares inferiores, tão monstro-medonhos, que Cristo mesmo lá só conseguiu aprofundar por um relance a graça de sua sustância alumiável" (ROSA, 2001, p. 79).

A análise do sentido da violência em Grande sertão: veredas aqui empreendida, além de ratificar a sua relevância na narrativa de Riobaldo, oferece-nos ainda mais indícios no sentido de uma confirmação da pertinência de uma leitura do romance de Guimarães Rosa sob a perspectiva das poéticas do mal. Ao emergir, ainda que de forma ambígua e tortuosa, como uma opção efetiva para a superação do medo, a violência torna-se um elemento essencial para as decisões do protagonista a respeito do modo como deve orientar a sua vida. Tratase de um componente que parece confirmar 0 papel fundamental desempenhado pela emoção do medo no percurso diegético e, sobretudo, ético de Riobaldo.

\section{Referências bibliográficas}

ARNT, Gustavo. Viver é muito perigoso: latifúndio e violência em Grande sertão: veredas. Gragoatá, Niterói, n. 39, p. 430-453, 2. sem. 2015.

BUENO, Giselle. O destapar do demônio: violência e trauma em Grande sertão: veredas. In: ANAIS eletrônicos do XI Congresso Internacional da ABRALIC. São Paulo: USP, 2008.

CANDIDO, Antonio. O homem dos avessos. In: Tese e antítese. São Paulo: Companhia Editora Nacional, 1964.

FRANÇA, J. O medo como elemento temático e estrutural de Grande Sertão: Veredas. In: ANAIS eletrônicos do XVI encontro internacional da ABRALIC. Brasília: UnB, 2020. [no prelo]

FRANÇA, J., ARAÚJO, Ana Paula. As artes e os atributos do Mal. In: As artes do mal; textos seminais. Rio de Janeiro: Bonecker, 2018.

GINZBURG, Jaime. A violência em Grande sertão: veredas. Revista do Instituto de Estudos Brasileiros, n.34, p. 87-99, 1992.

ROSA, João Guimarães. Grande sertão: veredas. 20 ed. Rio de Janeiro: Nova Fronteira, 2001. 